\title{
Knowledge, attitude and beliefs towards HIV/AIDS among students of health institutes in Sana'a city
}

\author{
N.A. Al-Rabeei, ${ }^{1}$ A.M. Dallak ${ }^{2}$ and F.G. Al-Awadi ${ }^{3}$
}

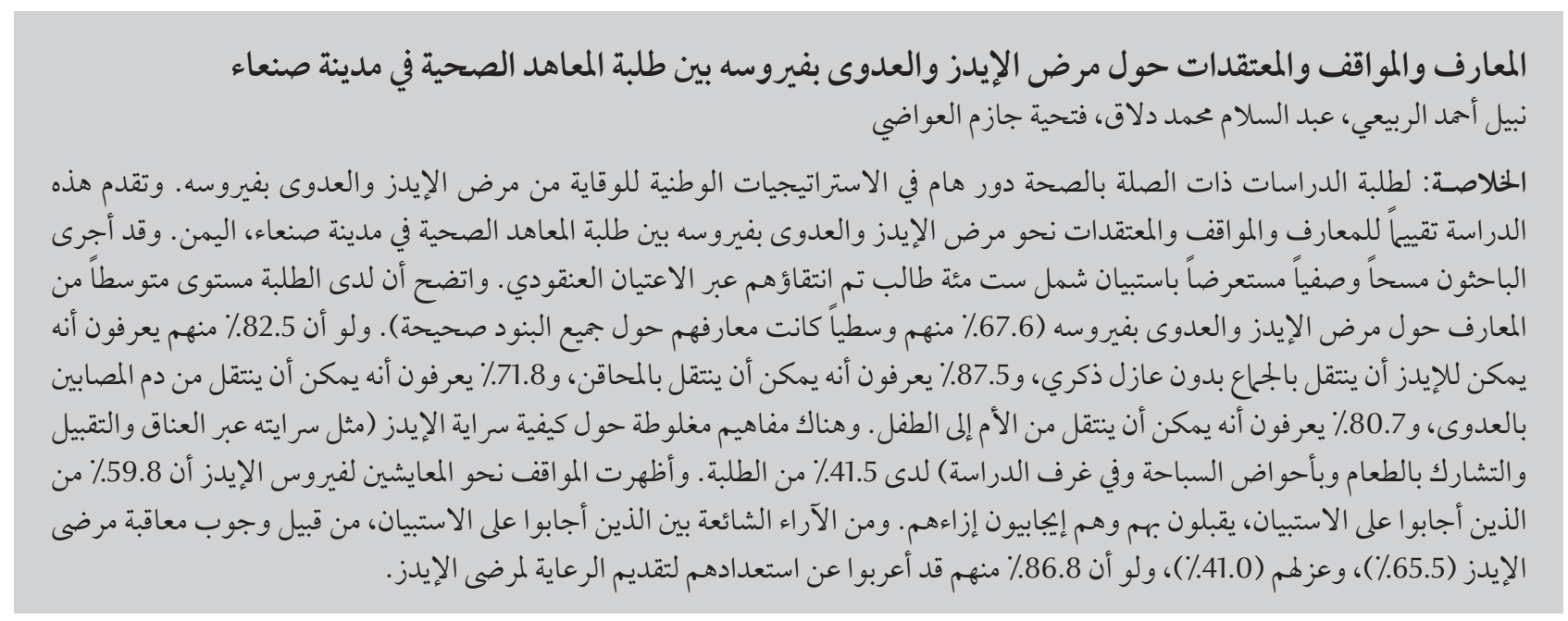

ABSTRACT Students of health-related subjects have an important role in national strategies on HIV/AIDS prevention. This study assessed the knowledge, attitudes and beliefs towards HIV/AIDS among students at health institutes in Sana'a city, Yemen. A descriptive cross-sectional questionnaire survey was conducted on 600 students selected by cluster sampling. Students had a moderate level of HIV/AIDS knowledge (an average of 67.6\% were correct on all items). Nevertheless, $82.3 \%$ knew that HIV could be transmitted by sexual intercourse without a condom, $87.5 \%$ from syringes, $71.8 \%$ from infected blood and $80.7 \%$ from mother to child. Misconceptions about how HIV is transmitted (e.g. hugging and kissing or sharing food, swimming pools and classrooms) were found among $41.5 \%$ of the students. Attitudes towards people living with HIV/AIDS showed that $59.8 \%$ of students were accepting and positive. There was a common opinion among respondents that HIV-infected persons needed to be punished (65.5\%) and isolated (41.0\%); however, 86.8\% were willing to care for an HIV-infected person.

Connaissances, attitudes et croyances des étudiants paramédicaux en matière de VIH/sida dans la ville de Sanaa

RÉSUMÉ Les étudiants paramédicaux jouent un rôle majeur dans les stratégies nationales pour la prévention de l'infection à VIH/du sida. La présente étude évalue les connaissances, attitudes et croyances des étudiants paramédicaux concernant le VIH/sida dans la ville de Sanaa (Yémen). Une enquête transversale descriptive par questionnaire a été menée auprès de 600 étudiants sélectionnés par échantillonnage en grappe. Les étudiants possédaient un niveau de connaissances sur le VIH/sida moyen $(67,6 \%$ d'entre eux ont répondu correctement à tous les items en moyenne). Toutefois, $82,3 \%$ d'entre eux savaient que le VIH pouvait être transmis par relation sexuelle sans préservatif, 87,5\% par les seringues, 71,8 \% par du sang contaminé et $80,7 \%$ de la mère à l'enfant. Des conceptions erronées sur le mode de transmission du VIH (exemples : par des accolades et des baisers ou le partage de nourriture, dans les piscines et les salles de classe) ont été observées chez 41,5\% des étudiants interrogés. Les questions sur les attitudes envers les personnes vivant avec le $\mathrm{VIH} /$ sida ont révélé que $59,8 \%$ des répondants étaient tolérants et positifs. Toutefois, ils étaient $65,5 \%$ à penser que les personnes infectées par le VIH devaient être punies et $41,0 \%$ à souhaiter les voir isoler. Malgré tout, 86,8 \% étaient disposés à soigner une personne infectée par le VIH.

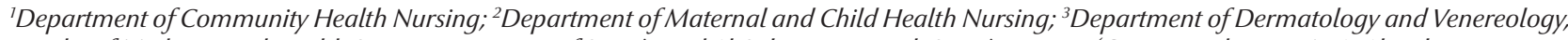
Faculty of Medicine and Health Science, University of Sana'a and Al-Sabeen Hospital, Sana'a, Yemen (Correspondence to N.A. Al-Rabeei: nabilalrabeei@hotmail.com).

Received: 12/04/10; accepted: 22/06/10 


\section{Introduction}

HIV/AIDS has killed more than 25 million people since it was first recognized in 1981, making it one of the most destructive epidemics in recorded history [1]. The total number of people living with the virus in 2008 was more than $20 \%$ higher than the number in 2000 and roughly 3 -fold higher than in 1990 [2]. Everyday, over 6800 persons become infected with HIV and over 5700 die from AIDS, mostly because of inadequate access to HIV prevention and treatment services.

An important factor fuelling the spread of HIV/AIDS in developing countries is believed to be poor knowledge about how the disease is spread and how it can be prevented. The results of a survey in Madagascar showed that $68 \%$ of participants in the study did not know that vaginal sex with a properly used condom is low risk [3]. A study of students in the Islamic Republic of Iran found that the knowledge of students about HIV/AIDS was only moderate $[4,5]$.

In Yemen AIDS is an increasing public health problem. In 1987 there was only 1 case, while by 2002 there were 1122 cases and the latest figures from 2008 showed the number of people with HIV/AIDS had reached 2075 [6]. Students of health-related subjects have an important role to play in national strategies on HIV/AIDS prevention. The aim of this study, therefore, was to assess the knowledge, attitudes and beliefs towards HIV/AIDS among students at health institutes in Sana'a city and to determine differences by sex and by institute.

\section{Methods}

\section{Study setting}

Sana'a city has 11 health institutes (1 government institute and 10 private institutes), in which students study for specialities such as physician's assistant, laboratory technician, midwife and pharmacy technician. The institutes provide graduate diplomas after 3 years of study. All institutes are recognized by the Yemeni Ministry of Public Health and Population.

\section{Sample and sampling}

This was a descriptive cross-sectional study conducted from January to March, 2010.

The target population was all students studying at health institutes in Sana'a city. The population estimates were 4198 students based on the most up-to-date figures available from the health institutes at the time. The sample size was calculated using Epi-Info, version 6.0, taking into consideration the following criteria: population size of 4198; expected frequency of $46 \%$ correct responses of participants toward modes of HIV transmission (based on a previous study in 2010 [7]) based on; worst acceptable $42 \%$. The total number of subjects required for our study with $95 \%$ confidence level was 522 students; taking into consideration a non-response rate of about $15 \%$, the final sample size was estimated as 600 students.

Cluster sampling was carried out in which students were selected from 6 health institutes within the 10 districts of Sana'a. A sampling frame of all students at the selected institutes, of all grades and specialty area, was used. All institutes had similar numbers of students so we selected 100 students randomly from each institute by a systematic random sampling to give a total of 600 students.

\section{Data collection}

Data were collected by the research team using a simplified, structured, self-administered questionnaire completed by students at their institute. It was thought that a self-administered questionnaire would offer participants greater freedom to express their attitudes when compared with the personal interview approach. The codes and names of the courses were identified by the administrative department of each institute. The teachers of these courses were approached at the beginning of each session and given a brief explanation of the study. Permission was obtained for students to take 15-20 minutes at the beginning of the class to complete the questionnaire. Students were instructed not to discuss the questions with their colleagues. If they had any queries, they were encouraged to ask a member of the research team. At the end of the session, the research team checked all questions had been answered and returned any questionnaires with missing information for the students to complete.

The questionnaire used for this study was based on the World Health Organization AIDS programme knowledge, attitudes, beliefs and practices survey in 1988 [8] and on other available literature $[9,10]$. It was translated into Arabic language and modified to suit the customs and culture of Yemen. The questionnaire started by outlining the benefits and aims of the study and recording the demographic characteristics of the study sample (age, sex, marital status, name of institute, level of education and department of study). The main questionnaire was divided into 4 parts with 22 questions: sources of information about HIV/AIDS (1 question); knowledge about HIV/ AIDS, e.g. causative agent and signs and symptoms (6 questions); beliefs about routes of HIV transmission (9 questions); and attitudes towards people living with HIV/AIDS (6 questions). Students were asked to mark the correct answer for each question (yes, no or don't know).

On each question, 1 point was awarded for a correct answer and 0 point for an incorrect choice or no response. Total scores for each student therefore ranged from $0-22$. Students with higher scores had greater HIV/ AIDS knowledge, good beliefs towards 
HIV transmission routes and more accepting attitudes towards people with HIV/AIDS.

The questionnaire was pilot tested on 20 students and was refined accordingly. No substantial difficulties were encountered during the testing and only minor corrections were made. The participants of the pilot study were not included in the final analysis.

\section{Ethical considerations}

Researchers informed the study participants about the general objectives of the study and that the questionnaires were anonymous in order to ensure the confidentiality of the information provided. None of the participants refused to participate in the study and informed consent was obtained orally.

\section{Statistical analysis}

SPSS, version 16.0, was used to enter and analyse the data. Epi-Info, version 6.0 was used to calculated sample size. The percentage of respondents with positive responses was calculated for each question. The total for each section was calculated as the average of the percentage correct responses. The chi-squared test was performed to test for differences in proportions, when appropriate, for categorical variables. $P<$ 0.05 was used as the level of significance.

\section{Results}

All 600 students completed the questionnaires; no discarded questionnaires or missing information were found. Table 1 summarizes the demographic characteristics of the respondents. The mean age was 19.0 (standard deviation $1.5)$ years. More than three-quarters (76.7\%) were male.

\section{Sources of HIV/AIDS information}

Students' sources of information about HIV/AIDS were diverse. Most students reported that mass media (newspapers,

\begin{tabular}{lcc}
\hline Table 1 Demographic characteristics of the respondents $(\boldsymbol{n}=\mathbf{6 0 0})$ & \\
Variable & No. of students & $\%$ \\
Sex & 460 & 76.7 \\
$\quad$ Male & 140 & 23.3 \\
$\quad$ Female & & \\
Specialty & 200 & 33.3 \\
$\quad$ Physician's assistant & 160 & 26.7 \\
Laboratory technician & 180 & 30.0 \\
Pharmacy technician & 60 & 10.0 \\
Midwife & & \\
Level of education & 350 & 58.3 \\
1st year & 200 & 33.3 \\
2nd year & 50 & 8.3 \\
3rd year & & \\
\hline
\end{tabular}

magazines, television and radio) were their major sources ofinformation about HIV/AIDS (313, 52.2\%), followed by the health institute $(133,22.2 \%)$. Some students had received their information from the Internet $(111,18.5 \%)$ or from health workers $(31,5.2 \%)$. Information was obtained from friends for only 12 students $(2.0 \%)$

\section{Knowledge about HIV/AIDS}

Responses to the knowledge questions showed that $85.3 \%$ of students knew AIDS is a communicable disease (14.7\% did not know); $88.6 \%$ that HIV is the causative agent of AIDS (11.4\% did not know); and $86.0 \%$ that the immune system is affected by HIV/AIDS (14.0\% did not know) (Table 2). Concerning signs and symptoms $37.7 \%$ agreed that fatigue was a symptom, $45.0 \%$ were aware that diarrhoea was a sign of HIV/AIDS and $62.1 \%$ were aware of weight loss as a sign of HIV/AIDS. Overall, students had moderate knowledge about HIV/AIDS; the average percentage of students answering questions in the knowledge section correctly was $67.6 \%$, while $32.4 \%$ were incorrect or did not know.

\section{Beliefs about HIV/AIDS}

Table 3 shows the responses to questions about modes of transmission of HIV. A higher proportion knew that HIV could be transmitted by infected syringes ( $87.5 \%)$, by sexual intercourse without a condom (82.3\%) and from mother to child ( $80.7 \%)$. There were some misconceptions, however, regarding non-transmissible methods. Fewer respondents knew that HIV cannot be transmitted through hugging and

\begin{tabular}{|c|c|c|}
\hline \multicolumn{3}{|c|}{$\begin{array}{l}\text { Table } 2 \text { Knowledge about HIV/AIDS among health care students in Sana'a, Yemen } \\
(n=600)\end{array}$} \\
\hline Item & $\begin{array}{l}\text { No of positive } \\
\text { responses }\end{array}$ & $\%$ \\
\hline AIDS is a communicable disease & 512 & 85.3 \\
\hline HIV is the causative agent of AIDS & 532 & 88.6 \\
\hline AIDS affects the immune system & 520 & 86.0 \\
\hline \multicolumn{3}{|l|}{ Signs and symptoms of AIDS: } \\
\hline Continued tiredness & 226 & 37.8 \\
\hline Chronic diarrhoea & 270 & 45.0 \\
\hline Rapid weight loss & 373 & 62.1 \\
\hline
\end{tabular}




\begin{tabular}{|c|c|c|}
\hline \multicolumn{3}{|c|}{$\begin{array}{l}\text { Table } 3 \text { Beliefs of health care students in Sana'a, Yemen, about transmission of HIV } \\
(\boldsymbol{n}=600)\end{array}$} \\
\hline Item & $\begin{array}{l}\text { No of positive } \\
\text { responses }\end{array}$ & $\%$ \\
\hline \multicolumn{3}{|l|}{ People can get HIV from: } \\
\hline Sexual intercourse without a condom & 494 & 82.3 \\
\hline Infected syringes and instruments & 525 & 87.5 \\
\hline Receiving infected blood & 431 & 71.8 \\
\hline Mother-to-child transmission & 484 & 80.7 \\
\hline \multicolumn{3}{|l|}{ People cannot get HIV from: } \\
\hline Hugging and kissing an infected person & 416 & 69.3 \\
\hline Insect bites & 342 & 57.0 \\
\hline Sharing food with an infected person & 195 & 32.5 \\
\hline Sharing public swimming pools & 368 & 61.3 \\
\hline From an infected person in the same classroom & 487 & 81.2 \\
\hline
\end{tabular}

kissing an infected person (69.3\%), by bites from mosquitoes and other insects $(69.3 \%)$ and by sharing public swimming pools (61.3\%) and only $32.5 \%$ agreed that sharing food with an infected person was not a risk. A high percentage (81.2\%) agreed that HIV cannot be transmitted via HIV-positive people in the same classroom. Overall, the average total response rate for acceptable beliefs was $58.5 \%$, while $41.5 \%$ of students had misconceptions or did not know the modes of HIV transmission.

\section{Attitudes toward HIV/AIDS}

Overall, respondents' attitudes towards people living with HIV/AIDS were moderate and positive - the average proportion with good attitudes was $59.8 \%$ - but many students (40.2\%) had negative attitudes toward HIV/ AIDS patients. Table 4 shows that only $35.2 \%$ were willing to live in the same community with HIV/AIDS people and $41.0 \%$ thought that people living with HIV/AIDS should be isolated. However, $64.0 \%$ would agree to work with people living with HIV/AIDS, HIV/AIDS should attend school and $65.5 \%$ would punish people with HIV/ AIDS. On the other hand, a high percentage of students (86.8\%) would be willing to care for a patient with HIV/ AIDS in special health setting.

\section{Differences by sex and institute}

The sex of respondents was not associated with the number of correctly answered questions on HIV/AIDS knowledge $\left(\chi^{2}=1.01 ; P>0.181\right)$, beliefs $\left(\chi^{2}=0.81 ; P>0.441\right)$ or attitudes. $\left(\chi^{2}=\right.$ $-1.153, P>0.221)$. In comparing different institutes, there were no statistically significant differences among students from different institutes in terms of $66.2 \%$ thought that children living with
HIV/AIDS knowledge $\left(\chi^{2}=1.81 ; P>\right.$ $0.241)$, beliefs $\left(\chi^{2}=2.01 ; P>1.241\right)$ or attitudes $\left(\chi^{2}=1.91 ; P>0.261\right)$.

\section{Discussion}

One group at higher risk of HIV/AIDS infection is students, some of whom may lack proper knowledge regarding the disease. Educational institutes therefore have the potential to become the focus of outbreaks, due to their large populations of young adults with high levels of close social contact. Knowledge, attitudes and beliefs studies are very useful tools prior to any intervention to assess the extent to which individuals or communities are in a position to adopt risk-free behaviours [11]. The major limitation of the current study was in designing the questionnaire. Since Yemen has a conservative, religious society, the research team was restricted in asking questions concerning respondents' sexual beliefs and behaviours.

\section{Sources of information about HIV/AIDS}

Our study found that mass media (newspapers, magazines, television and radio) were the most common ways for participants to receive information about HIV/AIDS, followed by their institute and the Internet. This study confirms previous research findings from Yemen that television is the current and probably the future leading source knowledge about HIV/AIDS [12]. The fact that television is one of

\begin{tabular}{lcc}
\hline Table 4 Attitudes of health care students in Sana'a, Yemen, towards people living with HIV/AIDS $(\boldsymbol{n}=\mathbf{6 0 0})$ & $\%$ \\
\hline Item & No of positive responses & 35.2 \\
Willing to live in the same community with people with HIV/AIDS & 211 & 86.8 \\
Willing to care for person with HIV/AIDS & 521 & 64.0 \\
Willing to work with person with HIV/AIDS & 384 & 41.0 \\
People with HIV/AIDS should be isolated & 246 & 66.2 \\
Children with HIV/AIDS should attend school & 397 & 65.5 \\
People with HIV/AIDS should be punished & 393 & \\
\hline
\end{tabular}


the few sources of information that is used equally by both males and females is also important as it can be used to increase knowledge that was underlined by this study. On the other hand, health workers had a less important role in educating people. This outcome is similar to other previous studies showing the important role of the mass media in raising people's awareness about AIDSrelated problems [13-15].

\section{Knowledge about HIV/AIDS}

Overall, the results from our study demonstrated that the students had a moderate level of HIV/AIDS knowledge, with only $67.6 \%$ on average having correct knowledge scores. This result is similar to studies conducted among students in Pakistan [16], Yemen [17] and in the Islamic Republic of Iran [4] and among the general population in Bandar-Abbas city, Islamic Republic of Iran [18]. It is also similar to other studies in China which were performed among university students [19-21], but much better than studies in China conducted among other groups, such as hotel attendants [22], criminal suspects [23] and others [24]. Similar results were observed with students of University of Sana'a [25] and in Sana'a city among the general population [12]. In a study conducted in the Islamic Republic of Iran in 2005 Montazeri reported that, despite some misconceptions, respondents had good knowledge about AIDS [13]. These differences may be because of differences in the study populations.

\section{Beliefs about HIV transmission}

The total percentage of correct responses about modes of transmission of HIV/AIDS was also moderate $(58.5 \%)$. Misconceptions about how HIV/AIDS is transmitted-e.g. by hugging and kissing, sharing food or drinking with an infected person, mosquito or insect bites, sharing public swimming pools and studying in the same classroom - were widely prevalent ( $41.5 \%$ on average) and show that students were not getting access to the right information about how HIV is transmitted. These findings were consistent with those of other studies in China [26,27], among young people in Mongolia [28] and Turkey [14] and in neighbouring Arab countries [29]. This issue was also addressed by previous research in Bangladesh and Greece $[30,31]$. The findings of those studies showed that half of the sample believed that HIV can be transmitted through kissing, using closed swimming pools and through mosquito and insects bites. According to UNICEF "surveys from 60 countries indicated that more than 50\% of young people aged 15-24 years had serious misconceptions about how HIV/AIDS is transmitted" [32]. Therefore, providing information about HIV/AIDS transmission that emphasizes the lack of scientific evidence for these beliefs should be a priority for any future information, education and communication campaigns about HIV/AIDS.

\section{Attitudes toward people with HIV/AIDS}

On average, the students' attitudes towards people living with HIV/ AIDS were diverse; $59.8 \%$ were accepting and positive while $40.2 \%$ were negative. Most of them would punish people with HIV/AIDS and believed they should receive specialized care in special health settings. Others thought that AIDS patients should not be punished but needed to be isolated. A low percentage of students were willing to live with people having HIV/AIDS in the same community and thought that children with HIV/AIDS should not attend the school. Similar attitudinal problems were found among young people from other developing countries, in the Islamic Republic of Iran [33], India [34] and China [35]. These findings are consistent with the findings of a study conducted in Tunisia [36]. This can be explained by the similar sociocultural setting of the population, especially in the light of religious factors. On the other hand, it may also be explained by the respondents having only moderate knowledge about HIV/AIDS. It has been shown that people in the community who do not know much about AIDS or do not know anyone with AIDS have less positive attitudes towards people living with HIV/AIDS [37]. Such serious attitudinal problems and widespread misconceptions caused by lack of education about AIDS need to be addressed.

\section{Conclusion}

In conclusion, there was a moderate level of knowledge among students in Sana'a health institutes, and a number of misconceptions and negative attitudes toward HIV/AIDS were common. These need to be addressed by health education programmes targeting those at higher risk. There should also be a big push to increase education about HIV/AIDS in educational institutes. More research about young people's HIV/AIDS knowledge, attitudes and beliefs needs to be done in Yemen.

\section{Acknowledgements}

We would like to thank the principals, teachers and students of Sana'a health institutes for their kind help and cooperation. 
1. Global AIDS epidemic continues to grow. Press release, $21 \mathrm{No}-$ vember 2006. Geneva, World Health Organization, 2006 (http://www.who.int/hiv/mediacentre/news62/en/index. html, accessed 5 November 2011).

2. AIDS epidemic update: December 2009. Geneva, Joint United Nations Programme on HIV/AIDS/World Health Organization, 2009 (UNAIDS/09.36E / JC1700E)

3. Lanouette NM et al. HIV- and AIDS-related knowledge, awareness, and practices in Madagascar. American Journal of Public Health, 2003, 93:917-919.

4. Tavoosi A et al. Knowledge and attitude towards HIV/AIDS among Iranian students. BMC Public Health, 2004, 4:17.

5. Nouhi Siahroudi A et al. Knowledge and attitude toward HIV/ AIDS among high school teachers of Polad Shahr, Isfahan. Paper presented at the 1st National Congress on Health Education, Yazd, Islamic Republic of Iran, 2003.

6. HIV/AIDS surveillance report. Sana'a, Yemen, AIDS and STD Control Programme, Ministry of Public Health and Population, 2008.

7. Al-Serouri AW et al. AIDS awareness and attitudes among Yemeni young people living in high-risk areas. Eastern Mediterranean Health Journal, 2010, 16(3):242-250.

8. Interview schedule on knowledge, attitude, beliefs and practices on AIDS/KABP survey. Geneva, World Health Organization, 1988 (WHO/GPA/SBR).

9. Xinming W. Research on knowledge, attitudes and sexual belief among university students in Quanzhou city. Chinese Journal of Health Education, 2003, 19:933.

10. AIDS-related knowledge, attitudes, behavior, and practices: a survey of 6 Chinese cities. Geneva, Joint United Nations Programme on HIV/AIDS/China HIV/AIDS Media Partnership, 2008.

11. National AIDS programmes: a guide to monitoring and evaluation. Geneva, Joint United Nations Programme on HIV/AIDS/ World Health Organization/MEASURE Evaluation Project, 2000 (UNAIDS/00.17).

12. Al-Serouri AW, Takiolidin M. Knowledge, attitude and beliefs about HIV/AIDS in Sana'a, Yemen. Eastern Mediterranean Health Journal, 2002, 8(6):706-715.

13. Montazeri A. AIDS knowledge and attitudes in Iran: results from a population-based survey in Tehran. Patient Education and Counseling, 2005, 57:199-203.

14. Ayranci U. AIDS knowledge and attitudes in a Turkish population: an epidemiological study. BMC Public Health, 2005, 5:95

15. Bakir B et al. Approaches of a group of soldiers in Istanbul and Ankara about AIDS. Gulhane Medical Journal, 2003, 45:19-24.

16. 16. Khan $\mathrm{H}$ et al. Knowledge and attitude of students regarding HIV/AIDS in Peshawar University. Journal of the Pakistan Medical Association, 2008, 33(1):9.

17. Al-Hababy MA et al. Knowledge, attitude and practices regarding HIV/AIDS among students of Sana'a University. Paper presented at the 20th Scientific Conference for Graduation Researches, Sana'a, Yemen, 1-2 September 2006.

18. Salehi SE et al. A population-based survey of HIV/AIDS knowledge and attitudes in general public, Bandar-Abbas, Iran. Pakistan Journal of Medical Sciences, 2008, 24(6):838-844.

19. Chen $\mathrm{G}$ et al. [A survey of AIDS related knowledge, attitude and behavior among college student $\mathrm{s}$ in 4 cities of Fujian, China]. Strait Journal of Preventive Medicine, 2005, 11:19-21 [in Chinese].
20. Li AL et al. A survey on STDs/ AIDS knowledge, perception and sexual behavior among university students in Beijing. Chinese Journal of Public Health, 1999, 15:545-546.

21. Jin $\mathrm{H}$, Honghong $\mathrm{W}$, Williams $A B$. [The relationship between knowledge and attitude about HIV/AIDS among university students in Changsha]. Practical Preventive Medicine, 2003, 10(4):454-458 [in Chinese].

22. Luo L, Tan X-D. [A survey on the knowledge, attitude, belief and practice related to AIDS among hotel attendants in Yichang city]. Zhejiang Journal of Preventive Medicine, 2005 17:11-13 [in Chinese].

23. Yand $P$ et al. [Survey on the knowledge of HIV/AIDS in criminal suspects]. Journal of Tropical Medicine, 2006, 6:328-330 [in Chinese].

24. Zhu H-B. Investigation of HIV knowledge among high risk groups in Maanshan city. Anhui Journal of Preventive Medicine, 2005, 11:17-18.

25. Ashwaq $\mathrm{M}$ et al. Knowledge and attitudes of HIV/AIDS among students of Sana'a University. Paper presented at the 18th Scientific Conference for Graduation Researches, Sana'a, Yemen, 13-14 October 2005

26. Wu Z, Pingping Y. [Research on knowledge, attitudes and practice about AIDS among university students in Fujian Province]. Journal of Fujian Medical University, 2002, 34(2):194-196 [in Chinese].

27. Jichuan C. [Investigation on knowledge, practice about STDs and AIDS among Ningde normal school students]. Chinese Journal of Health Education, 2003, 19:853-854 [In Chinese].

28. Sodnompil TS et al. Knowledge, attitude and practice survey on STD/HIV/AIDS for young persons 15-25 years old in Mongolia. Paper presented at the 2nd International Conference on Primary Health Care Melbourne, Victoria, Australia, 17-20 April 2000.

29. Al-Owish $\mathrm{R}$ et al. Knowledge, attitudes, beliefs and practice about HIV/AIDS in Kuwait. AIDS Education and Prevention, 1999, 11:163-173.

30. Rahman M. et al. Knowledge, attitudes, beliefs and practices about HIV/AIDS among the overseas job seekers in Bangladesh. Public Health, 1999, 113:35-38.

31. Merakou K, Costopoulos C. Knowledge, attitude, and behavior after 15 years of HIV/AIDS prevention in school. European Journal of Public Health, 2002, 12:90-93.

32. Young people and HIV/AIDS: opportunity in crisis. New York, United Nations Children's Fund, 2002.

33. Anahita T et al. Knowledge and attitude toward HIV/AIDS among Iranian students. BMC Public Health, 2004, 4:17.

34. Agrawal HK et al. Knowledge of and attitude to HIV/AIDS of senior secondary school pupils and trainee teachers in Udupi district, Karnataka, India. Annals of Tropical Paediatrics, 1999, 19:143-149.

35. Tan X et al. HIV/AIDS Knowledge, attitudes and behaviors assessment of chinese students: a questionnaire study. International Journal of Environmental Research and Public Health, 2007, 4:248-253

36. Tebourski F, Ben Alaya D. Knowledge and attitude of high school student regarding HIV/AIDS in Tunisia; does more knowledge lead to more positive attitude? Journal of Adolescent Health, 2004, 34:161-164.

37. Jaiswal S et al. HIV/AIDS and STI related knowledge, attitude and practice among high school students in Kathmandu valley. Kathmandu University Medical Journal, 2005, 3(1) :69-67. 